\title{
COVID- 19 PANDEMIC AND THE PROTECTION OF THE RIGHT TO ABORTION
}

\author{
Ivana Tucak, PhD, Associate Professor \\ Josip Juraj Strossmayer University of Osijek, Faculty of Law \\ Stjepana Radića 13, Osijek, Croatia \\ itucak@pravos.hr
}

\author{
Anita Blagojević, PhD, Associate Professor \\ Josip Juraj Strossmayer University of Osijek, Faculty of Law \\ Stjepana Radića 13, Osijek, Croatia \\ ablagoje@pravos.hr
}

\begin{abstract}
The COVID - 19 pandemic that swept the world in 2020 and the reactions of state authorities to it are unparalleled events in modern history. In order to protect public health, states have limited a number of fundamental human rights that individuals have in accordance with national constitutions and international conventions. The focus of this paper is the right of access to abortion in the Member States of the European Union. In Europe, the situation with regard to the recognition of women's right to abortion is quite clear. All member states of the European Union, with the exception of Poland and Malta, recognize the rather liberal right of a woman to have an abortion in a certain period of time after conception. However, Malta and Poland, as members of the European Union, since abortion is seen as a service, must not hinder the travel of women abroad to have an abortion, nor restrict information on the provision of abortion services in other countries.
\end{abstract}

In 2020, a pandemic highlighted all the weaknesses of this regime by preventing women from traveling to more liberal countries to perform abortions, thus calling into question their right to choose and protect their sexual and reproductive rights. This is not only the case in Poland and Malta, but also in countries that recognize the right to abortion but make it conditional on certain non-medical conditions, such as compulsory counselling; and the mandatory time period between applying for and performing an abortion; in situations present in certain countries where the problem of a woman exercising the right to abortion is a large number of doctors who do not provide this service based on their right to conscience.

The paper is divided into three parts. The aim of the first part of the paper is to consider all the legal difficulties that women face in accessing abortion during the COVID -19 pandemic, restrictions that affect the protection of their dignity, right to life, privacy and right to equality. In 
the second part of the paper particular attention will be paid to the illiberal tendencies present in this period in some countries of Central and Eastern Europe, especially Poland. In the third part of the paper, emphasis will be put on the situation in Malta where there is a complete ban on abortion even in the case when the life of a pregnant woman is in danger.

Keywords: Covid -19 pandemic, Abortion on Request, Telemedicine, European Convention on Human Rights, Autonomy, Dignity

\section{INTRODUCTION}

The COVID - 19 pandemic that swept the world in 2020 and the reactions of state authorities to it are unparalleled events in modern history. The pandemic was accompanied by extreme pressure on the health systems of the states and the introduction of measures to restrict the movement of individuals, i.e. the closure of state borders. In order to protect public health, states have limited a number of fundamental human rights that individuals have in accordance with national constitutions and international conventions.

A number of constitutional courts questioned the adequacy of the introduced state measures, the legitimacy of their goals, i.e. the proportionality of the introduced restrictions on human rights in relation to the existing threats to public health. ${ }^{1}$ In this paper, the focus will be on the right of access to abortion in the Member States of the European Union.

It is important to note that in Europe, the situation with regard to the recognition of women's right to abortion is quite clear. All member states of the European Union, with the exception of Poland and Malta, recognize the rather liberal right of a woman to have an abortion in a certain period of time after conception. However, Malta and Poland, as members of the European Union, since abortion is seen as a service, must not hinder the travel of women abroad to have an abortion, nor restrict information on the provision of abortion services in other countries. Abortion thus emerges as a form of cross-border reproductive care. ${ }^{2}$

Following the number of submissions for constitutional review of the legislative and other measures adopted in the context of the pandemic the Constitutional Court of the Republic of Croatia in its Decision of 14 September 2020 questioned, inter alia, the authority of the Civil Protection Headquarters for adopting measures restricting human rights.

The Constitutional Court of the Republic of Croatia, Decision No. U-I-1372/2020 and others from 14 September 2020, available on: [https://sljeme.usud.hr/usud/praksaw.nsf/C12570D30061CE54C12585E7002A7E7C/\$FILE/SA\%c5\%bdETAK\%20-\%20COVID-19.pdf], Accessed 20 April 2020.

2 See more on this issue: Tucak, I.; Blagojević, A., Abortion in Europe, EU and comparative law issues and challenges series (ECLIC), Vol. 4 (2020): EU 2020 - lessons from the past and solutions for the future; Mulligan, A., The Right to Travel for Abortion Services: A Case Study in Irish Cross-Border Reproductive Care, European Journal of Health Law, Vol. 22, No. 3, 2015, pp. 239-266. 
In 2020, a pandemic highlighted all the weaknesses of this regime by preventing women from traveling to more liberal countries to perform abortions, thus calling into question their right to choose and protect their sexual and reproductive rights. This is not only the case in Poland and Malta, but also in countries that recognize the right to abortion but make it conditional on certain non-medical conditions, such as compulsory counselling; and the mandatory time period between applying for and performing an abortion; in situations present in certain countries where the problem of a woman exercising the right to abortion is a large number of doctors who do not provide this service based on their right to conscience.

As for the Council of Europe's position on abortion, the Parliamentary Assembly of the Council of Europe called on its member states to "guarantee women's effective exercise of their right of access to a safe and legal abortion". ${ }^{3}$ The European Court of Human Rights did not issue a substantive verdict on abortion but pointed out that member states are obliged to comply with their abortion legislation. ${ }^{4}$ This means that states that allow abortion on demand (regardless of medical reasons) are required "to ensure the effectiveness of this right". ${ }^{5}$ It is also important to emphasize that the case law of the European Court of Human Rights also supports the principle of the inherent dignity of persons who may become pregnant. ${ }^{6}$ For example, this is evident in decisions relating to the forced sterilization of women, mainly from marginalized groups or certain ethnic groups, which state that this violates not only their right to health but also their dignity. ${ }^{7}$

The paper is divided into three parts. The aim of the first part of the paper is to consider all the legal difficulties that women face in accessing abortion during the COVID -19 pandemic, restrictions that affect the protection of their dignity, right to life, privacy and right to equality. In the second part of the paper particular

On Poland and Malta see European Parliament's Committee on Women's Right and Gender Equality, Access to abortion services for women in the EU, report made by Blagojević, A. and Tucak I., September 2020, [https://www.europarl.europa.eu/RegData/etudes/IDAN/2020/659923/IPOL_ IDA(2020)659923_EN.pdf], Accessed 20 April 2020.

3 McGuinness, S.; Montgomery, J., Legal Determinants of Health: Regulating Abortion Care, Public Health Ethics, Vol. 13, No. 1, 2020, p. 35; Parliamentary Assembly of the Council of Europe, Resolution 1607 (2008), Access to Safe and Legal Abortion in Europe, [http://assembly.coe.int/nw/xml/ XRef/Xref-XML2HTML-en.asp?fileid=17638], Accessed 11 April 2021.

$4 \quad$ McGuinness, S.; Montgomery, J., op. cit., note 3, p. 35.

5 Lebret, A., COVID-19 pandemic and derogation to human rights, Journal of Law and the Biosciences, Vol. 7, No. 1, 2020, pp. 14-15; See A., B. and C v. Ireland (2011) 53 E.H.R.R 13; R. R. v. Poland (2011) 53 EHRR 31 and Tysiqc v. Poland (2007) 45 EHRR 42.

6 Yamin, A. E.; Boghosian, T., Democracy and Health: Situating Health Rights within a Republic of Reasons, Yale J. Health Pol'y L. \& Ethics, Vol. 19, 2020, p. 110.

7 V.C. v. Slovakia (2011)-V Eur. Ct. H.R. 381; Yamin op. cit., note 6, p. 110. 
attention will be paid to the illiberal tendencies present in this period in some countries of Central and Eastern Europe, especially Poland. In its judgment of 22 October 2020 the Polish Constitutional Court addressed the issue of eugenic abortion and held that it is contrary to the Polish Constitution. In the last part of the paper, the emphasis will be on the situation in Malta where there is a complete ban on abortion even in the case when the life of a pregnant woman is in danger. The problematic situation in Poland and Malta was also highlighted in recent European Parliament's Committee on Women's Right and Gender Equality report "Access to abortion services for women in the EU" (September 2020). ${ }^{8}$

\section{COVID - 19 PANDEMIC}

The coronavirus SARS CoV-2 (Severe Acute Respiratory Syndrome Coronavirus-2) was detected in Wuhan, China and reported to the World Health Organization (hereinafter "WHO") on 31 December 2019. ' COVID-19 is the name of a disease caused by this virus. ${ }^{10}$ On 30 January 2020, the WHO described it as "a public health emergency of international concern", and on 11 March 2020 as a pandemic. ${ }^{11}$ According to data from 1 June 2021, 174,582,356 cases and $3,764,746$ deaths were recorded globally, while 2,242,769,750 people were vaccinated. ${ }^{12}$ Although it is a new hitherto unknown virus, it is important to emphasize that the WHO has long pointed out the danger of a global pandemic of influenza and in 2019 it was ranked among the ten biggest threats to global health. The WHO predicted that this pandemic would surely occur: "The only thing we don't know is when it will hit and how severe it will be." 13

The appearance of this disease occurred at the time of the greatest mobility of people and the global interconnectedness enabled its rapid spread. ${ }^{14}$ The exponential rise

8 European Parliament's Committee on Women's Right and Gender Equality, Access to abortion services for women in the EU, report made by Blagojević, A. and Tucak I., September 2020, [https://www. europarl.europa.eu/RegData/etudes/IDAN/2020/659923/IPOL_IDA(2020)659923_EN.pdf], Accessed 20 April 2020.

9 Thomson, S., C.; Ip, E., COVID-19 emergency measures and the impending authoritarian pandemic, Journal of Law and the Biosciences, Vol. 7. No. 1. 2020, 2.

10 See Najčešća pitanja i odgovori za koronu.pdf, [https://www.zzjzpgz.hr/obavijesti/2020/Naj\%C4\%8De\%C5\%A1\%C4\%87a\%20pitanja\%20i\%20odgovori\%20za\%20koronu.pdf], Accessed 20 April 2020.

11 Thomson, S., C.; Ip, E., op. cit., note 9, p. 2.

12 John Hopkins University of Medicine, Coronavirus Resource Center, [https://coronavirus.jhu.edu/ map.html], Accessed 1 June 2021.

13 World Health Organization, Ten threats to global health in 2019 [https://www.who.int/news-room/ spotlight/ten-threats-to-global-health-in-2019], Accessed 1 June 2021.

14 Thomson, S., C.; Ip, E., op. cit., note 9, p. 7. 
in infection and mortality rates has brought the health systems of many states to the brink. ${ }^{15}$ Healthcare providers are facing the challenge of continuing to provide standard healthcare services while tackling a new and unknown infectious disease. ${ }^{16}$ The capacities of intensive care units and morgues proved to be insufficient for the new needs, there was, among other things, a shortage of testing equipment, personal protective equipment, and mechanical ventilators. ${ }^{17}$ States have introduced unprecedented measures to prevent the spread of infection, closed their borders, some have prevented the movement of their own population between cities and regions. ${ }^{18}$

In the efforts of states to stop the spread of this new type of coronavirus, there has been an increase in authoritarianism, ${ }^{19}$ not only in states that have already been described as "disciplinary" or "tyrannical" but also in liberal democracies. ${ }^{20}$ What is an unprecedented event is the fact that the COVID-19 pandemic has triggered the establishment of states of emergency, officially or de facto not only in one or two states but in most states. ${ }^{21}$

The authors describe the new situation as a constitutional "pandemic" that led to a decline towards authoritarianism. ${ }^{22}$ In the long run, with all the restrictions on fundamental human rights and freedoms, but also on a health ethic based on human dignity and autonomy, this crisis could have consequences as severe as those following the COVID-19 pandemic. ${ }^{23}$ One can speak of a constitutional pandemic because the abuse of public health emergency powers poses a threat to modern constitutionalism aimed at limiting state power. ${ }^{24}$

Some countries have taken advantage of this emergency to declare abortion an "elective procedure" rather than an "essential medical service" 25 and have thus made it impossible for women to access abortion due to the "time-sensitive" 26

\footnotetext{
15 Ibid., 1.

16 Prandini Assis, M.; Larrea, S., Why self-managed abortion is so much more than a provisional solution for times of pandemic, Sexual and Reproductive Health Matters, Vol. 28, No. 1, 2020, 1.

17 Thomson, S., C.; Ip, E., op. cit., note 9, p. 2.

18 Ibid., 2.

19 Ibid., 1.

20 Ibid., 4.

21 Ibid.

22 Ibid., 5.

23 Ibid., pp. 1, 4.

24 Ibid., 5.

25 Todd-Gher, J.; Shah, P. K., Abortion in the context of COVID-19: a human rights imperative, Sexual and Reproductive Health Matters, Vol. 28, No. 1, 2020, p. 29.

26 Romanis, E. C.; Parsons, J. A., Legal and Policy Responses to the Delivery of Abortion Care During COVID-19, International Journal of Gynecology and Obstetrics 2020 (Dec), p. 4.
} 
nature of the procedure. ${ }^{27}$ Among the countries that have not recognized abortion as an essential medical service are, for example, Germany, Austria and Croatia. ${ }^{28}$ This practice is contrary to the position of the WHO, which described reproductive health care as an "essential health service that must be accorded high priority in COVID-19 response." ${ }^{29}$ Some countries have gone even further in restricting access to abortion. For example, the Slovak government has issued a statement saying that access to abortion is not recommended at this time. ${ }^{30}$

When we talk about pregnancy and access to abortion, it is important to point out that we need more precise terminology, it is common to talk about the right of women to access abortion, but it is more precise to talk about the right of access to abortion of persons who may become pregnant. ${ }^{31}$ Women are not the only ones who can get pregnant; so can transgendered males, nonbinary persons, and cis-gender women. ${ }^{32}$

Although in this paper we discuss the regulation of abortion in the countries of the European Union, it is important to emphasize that the EU only has "a supporting competence" in the field of health. ${ }^{33}$ According to Article 6 of the consolidated version of the Treaty on the Functioning of the EU (TFEU)with regard to the protection and promotion of health, ${ }^{34}$ the Union has the "competence to carry out actions to support, coordinate or supplement the actions of the Member States". ${ }^{35}$

\subsection{THE CONNECTION BETWEEN LAW AND HEALTH}

Health is not only related to "individual behaviors or biological pathogens" but is mostly "a product of social structures and relations" and can therefore be concep-

$27 \quad$ Prandini Assis, M.; Larrea, S., op. cit., note 16, p. 1.

28 Romanis, E. C.; Parsons, J. A., op. cit., note 26, p. 7.

29 WHO. WHO releases guidelines to help countries maintain essential health services during the COVID-19 pandemic. 2020 Mar 30. [https://www.who], Accessed 20 April 2021.

[int/news-room/detail/30-03-2020-who-releases-guidelinesto-help-countries-maintain-essential-health-servicesduring-the-covid-19-pandemic], according to Todd-Gher, J.; Shah, P. K., op. cit., note 25 , p. 29.

30 Romanis, E. C.; Parsons, J. A., op. cit., note 26, p. 7.

31 Yamin op. cit., note 6, p. 110.

32 Nandagiri, R.; Coast, E.; Strong, J., COVID-19 and Abortion: Making Structural Violence Visible, International Perspectives on Sexual and Reproductive Health, Vol. 46, No. Supplement 1, Focus on Abortion (2020), p. 83. Nandagiri et al. use the terms "womxn"; See also Romanis, E. C.; Parsons, J. A., op. cit., note 26 , p. 1.

33 Lebret, op. cit., note 5, pp. 1-2.

34 Article 6 (a) of the consolidated version of the TFEU.

35 Lebret, op. cit., note 5, p. 2. See also Article 168 TFEU relating to public health. 
tualized as a moral and legal right. ${ }^{36}$ The law as one of the important means for the promotion and advancement of health is still insufficiently understood and used. ${ }^{37}$ Poorly designed laws, as well as those that are not properly enforced, can particularly harm marginalized groups of people and contribute to discrimination. ${ }^{38}$

In this context, it is instructive to present the results of the McGuinness analysis based on the work of the Lancet-O'Neill Commission on Global Health and Law called The legal determinants of health: Harnessing the power of law for global health and sustainable development.

Law can be seen as a weapon in "culture wars" ${ }^{39}$ For these reasons, no agreement has yet been reached on the human rights dimension of abortion, and even health aspects have been obscured. ${ }^{40}$ The issue of abortion is seen primarily as a moral issue on which it is necessary to reach a compromise between the conflicting parties. ${ }^{41}$ Such an approach is harmful. ${ }^{42}$

Throughout history, arbitrary and discriminatory laws have inflicted great harm on individuals and groups. ${ }^{43}$ Criminal legislation did injustice to women and restricted their sexual and reproductive rights. ${ }^{44}$ Existing legal frameworks often do not guarantee "clinically optimal care" but, in case they are based on the morality of abortion, interfere with "good clinical practice". 45

Health systems may be "gender-blind", but this does not mean that they are neutral. ${ }^{46}$ When regulating sexual and reproductive rights, states may impose restrictions on access to health care that are not only unnecessary but also harmful. ${ }^{47}$ They are a participant in the making of "gendered harms". ${ }^{48}$

36 Yamin op. cit., note 6, p. 101.

37 McGuinness, S.; Montgomery, J., op. cit., note 3, p. 34; Gostin, L.; Monahan, J.; Kaldor, J.; Debartolo, M.; Friedman, E.; Gottschalk, K.; Kim, S. C.; Alwan, A.; Binagwaho, A.; Burci, G. L.; Cabal, L.; DeLand, K.; Evans, T. G.; Goosby, E.; Hossain, S.; Koh, H.; Ooms, G.; Periago, M. R.; Uprimny, R.; and Yamin, A. E., The Legal Determinants of Health: Harnessing the Power of Law for Global Health and Sustainable Development, The Lancet, 393, 2019, p. 1857.

$38 \quad$ Ibid., 1857.

39 McGuinness, S.; Montgomery, J., op. cit., note 3, p. 35.

$40 \quad$ Ibid., 35.

41 Ibid., 36.

42 Ibid.

43 Ibid., 35; Gostin et al, op. cit., note 37, p.1859.

$44 \quad$ Ibid.; Gostin et al, op. cit., note 37, p.1890.

45 Ibid., 34.

46 Ibid., 36.

47 Ibid.

48 Ibid. 
As examples of such harmful restrictions on the possibility of performing an abortion, McGuinness lists "medically unnecessary waiting periods, unnecessary informed consent rules, parental notification requirements and clinically unnecessary restrictions on where and by whom abortions may be performed." ${ }^{49}$ These restrictions contribute to the stigmatization of abortion and have a particularly detrimental effect on women of low socioeconomic status. ${ }^{50}$ Also, the refusal of doctors to perform abortions by invoking the institute of conscientious objection stigmatizes this procedure as well as those who undergo it. ${ }^{51}$ All persons must be able to actively decide in the area of sexual and reproductive freedoms, and must not be merely passive recipients of "reproductive health services". ${ }^{52}$ Only the full reproductive freedom of persons who may become pregnant enables them to be equal members of the social community, i.e. equal legal subjects. ${ }^{53}$

\section{THE RIGHT OF ACCESS TO ABORTION IN THE EU DURING THE COVID-19 PANDEMIC}

Today, in most of Europe, abortion laws are a kind of "moral compromise", according to which women are allowed to have an abortion on demand in the first trimester of pregnancy, and after that time period their access is limited. ${ }^{54}$ Abortion due to non-medical indications is widely available in Europe, but the legal regulation of the abortion procedure itself is diverse. ${ }^{55}$

As we saw in the previous chapter, even prior to the COVID-19 pandemic, in "normal" times, pregnant women were faced with numerous barriers to exercising their right to abortion, in spite of the fact that this right is "central to gender equality, human rights, and social justice" 56 Those barriers differed from state to

\footnotetext{
49 Ibid.

50 Ibid.

51 Ibid.

52 Yamin op. cit., note 6, p. 110.

53 Ibid.

54 Allen, A., "Privacy and Medicine", The Stanford Encyclopedia of Philosophy (Spring 2021 Edition), Edward N. Zalta (ed.), [https://plato.stanford.edu/archives/spr2021/entries/privacy-medicine/], Accessed 11 April 2021.

55 Moreau et al, Abortion regulation in Europe in the era of COVID-19: a spectrum of policy responses, BMJ Sex Reprod Health, 2020, [https://srh.bmj.com/content/familyplanning/early/2021/02/22/bmjsrh-2020-200724.full.pdf], Accessed 3 April 2021, p. 2.

56 Mishtal, J.; Martino, A.; Zanini, G.; Capelli, I.; Rahm, L.; DeZordo S., Political (in)action in abortion governance during COVID-19 in Europe: a call for a harmonized EU response during public health crises, Medical Anthropology Quarterly, 2020, available on: [https://medanthroquarterly.org/rapid-re-
} 
state and encompassed differing legal, social and procedural aspects. ${ }^{57}$ Moreau et al. divide these various measures to restrict access to abortion into two categories: ${ }^{58}$

"On the demand side, measures include mandatory counselling and waiting periods, parental consent, funding regulations or bureaucratic requirements (e.g. authorisation by several doctors)."

"On the supply side, restrictions apply to the type of provider who can perform abortions, the type of medical interactions (in-person consultations vs remote consultations), the modalities of medication dispensation or the types of additional examination or procedures required (for gestational dating, anti-D immunoglobulin injection for women with Rhesus-negative blood group)."

The above restrictions are not based on science and place unnecessary barriers to abortion seekers. ${ }^{59}$

However, the impact of the pandemic on sexual and reproductive health and rights in general, and on access to abortion in particular, is enormous. Available reports and studies show that the lack of harmonized policy response to pandemic has widened the existing inequities in access to abortion in Europe. ${ }^{60}$

Access to contraception and abortion is further limited during a pandemic. ${ }^{61}$ The reorganization of work in hospitals has led to a delay in performing abortions. ${ }^{62}$ Some countries have enacted "gender neutral emergency regulations" that do not satisfactorily address emerging issues, and some have even used the new situation to remove existing rights. ${ }^{63}$ Lockdowns and quarantines restricting freedom of movement have also exacerbated existing abortion restrictions requiring multiple clinic visits which increases the risk of infection for abortion seekers and health care providers themselves. ${ }^{64}$ In addition, the pandemic has also jeopardized the supply of birth control pills as well as abortion medications. ${ }^{65}$

sponse/2020/06/political-inaction-in-abortion-governance-during-covid-19-in-europe/], Accessed 3 April 2021.

57 Pinter, B.; Aubeny, E.; Bartai, G.; Loeber, O.; Ozalp, S.; Webb, A., Accessibility and availability of abortion in six European countries, The European Journal of Contraception and Reproductive Health Care, Vol. 10, No. 1, 2005, p. 56-57.

58 Moreau et al., op. cit., note 55, p. 2.

59 Ibid.

60 Ibid., 1.

${ }^{61}$ Lebret, op. cit., note 5, p. 14.

62 Ibid.

63 Ibid.

64 Todd-Gher, J.; Shah, P. K., op. cit., note 25, p. 28.

65 Ibid. 
The COVID-19 pandemic is believed to increase the need for abortion both due to the increase in domestic violence and income insecurities. ${ }^{66}$ Several countries reported that there was a serious increase in domestic violence during the COVID-19 pandemic, which has been identified by the WHO as a significant public health problem. ${ }^{67}$ The UN Committee on the Elimination of Discrimination against Women described the "prohibition of gender-based violence" as a "principle of customary international law". ${ }^{68}$ Forced continuation of an unwanted pregnancy has been recognized in several situations as a violation of human rights, especially where physical or mental influences on pregnant women are present. ${ }^{69}$

According to research by 100 European NGOs, the effect of the pandemic on access to abortion is threefold: firstly, in several European countries, the existing barriers to abortion access have been exacerbated (for example, in Romania, Germany, Italy, the Netherlands, Ireland, Spain); secondly, in some countries, negative steps aimed at further coercion measures were detected (for example, in Lithuania, Hungary, Poland); and thirdly, some countries took significant positive, progressive steps forward in the context of securing the right to abortion (for example, in the context of the promotion of telemedicine in the UK and France).$^{70}$

Similar results were obtained by Moreau et al. in their analysis of policy responses enacted in 46 European countries/regions related to access to abortion services during the COVID-19 pandemic. Their research showed that, within the context of the pandemic, abortion "was available to varying extents in 39 countries/ regions, banned for non-medical reasons in six countries (Andorra, Liechtenstein, Malta, Monaco, San Marino and Poland) and suspended in Hungary due to a ban on non-life-threatening surgeries in state hospitals" ${ }^{71}$ According to this research, the situation in Croatia with regard to the abortion regulation during Covid-19 pandemic is as follows: gestational limit for non-medical indications is 10 weeks, there is mandatory waiting period, home abortion is not permitted, there is no

$66 \quad$ Ibid.; See also Moreau et al., op. cit., note 55, p. 1.

67 Lebret, op. cit., note 5, p. 9; See UN Women, "COVID-19 and Ending Violence against Women and Girls", [https://asiapacific.unwomen.org/-/media/field\%20office\%20eseasia/docs/publications/2020/04/hq_covid-19_photos.pdf?la=en\&vs=902], Accessed 10 May 2021.

68 Lebret, op. cit., note 5, p. 9; See UN Women, "COVID-19 and Ending Violence against Women and Girls.” CEDAW, General recommendation No. 35 on gender-based violence against women, updating general recommendation No. 19, 14 July, 2017, at 2. CEDAW/C/GC/35.

69 Todd-Gher, J.; Shah, P. K., op. cit., note 25, p. 28.

70 IPPF European Network \& European Parliamentary Forum for Sexual and Reproductive Health and Rights, Sexual and Reproductive Health and Rights during the COVID-19 pandemic, A joint report, 22 April 2020, available on: [https:/www.ippfen.org/sites/ippfen/files/2020-04/Sexual\%20and\%20Reproductive\%20Health\%20during\%20the\%20COVID-19\%20pandemic.pdf], Accessed 6 April 2021.

71 Moreau et al., op. cit., note 55, p. 2. 
availability of telemedicine, and the access to mifepristone is only possible in the clinic or the hospital. ${ }^{72}$ In addition, in Croatia abortion was not recognize as essential service. ${ }^{73}$ The activists of the Platform for Reproductive Justice warned that the access to abortion in Croatia became even more inaccessible and expensive during the pandemic. ${ }^{74}$ According to their investigation, eight of 29 authorized hospitals do not perform this procedure and even in hospital that perform the procedure it is difficult to get appropriate information. ${ }^{75}$

France deserves particular attention among countries that recorded a positive and swift reaction in the context of ensuring the right to abortion during the pandemic. A swift reaction and mobilization of abortion professionals, women's associations, perinatal networks and regional health agencies resulted in a decision by the French authorities to adapt the abortion services and introduce several exceptions, such as the extended access to medical abortion at home from seven to nine weeks of pregnancy and introduction of telemedicine for medical abortion consultation. ${ }^{76}$ Furthermore, during surgical abortion planning, the practice promoting local over general anaesthesia is observed, and all examinations and consultations are performed as outpatient procedures, instead of taking several days as was the case before the pandemic. ${ }^{77}$ Still, it should be pointed out that, despite these measures, French hospitals recorded a drastic decline in the number of women seeking an abortion during the lockdown, which has been linked to "psychological barriers to services, and general physical immobility during lockdown". ${ }^{78}$

France's success in this area is related to telemedicine, and in the next subchapter we will point out its importance in providing abortion services.

\subsection{Telemedicine}

Women and "gender non-conforming people" have long been fighting for the "demedicalization of their bodies and health". ${ }^{79}$ The problem is that a public health-

\footnotetext{
Ibid., p. 6.
}

Romanis, E. C.; Parsons, J. A., op. cit., note 26, p. 7.

74 Pobačaj još nedostupniji i skuplji: cijene i do 3000 kuna, sve veći broj liječnika u prizivu savjesti, RTL vijesti, 28 April 2020, available on: [https:/www.rtl.hr/vijesti-hr/novosti/hrvatska/3807661/pobacaj-zbog-pandemije-jos-nedostupniji-cijene-i-do-3000-kuna-sve-veci-broj-lijecnika-u-prizivu-savjesti/], Accessed 7 April 2021.

75 Ibid.

76 Mishtal et al., op. cit., note 56.

77 Ibid.

78 Ibid.

79 Prandini Assis, M.; Larrea, S., op. cit., note 16, p. 2. On telemedicine and self-managed abortion see also European Parliament's Committee on Women's Right and Gender Equality, Access to abortion 
based approach to the term "quality of care" does not include autonomy and control. ${ }^{80}$ Abortion took place within "intimate circles of care" until the 19th century when this issue began to be regulated by law, i.e. a period of "medicalization of abortion" began. ${ }^{81}$ During the COVID-19 pandemic, the issue of self-managed abortion was again emphasized. Access to abortion in these times of crisis can be facilitated "by providing early medical abortion (EMA) through telemedical services (TEMA)" ${ }^{82}$

"EMA is the use of two drugs - mifepristone and misoprostol - taken 24-48 hours apart to procure an abortion". ${ }^{83}$

"TEMA is the use of telemedical means to provide EMA remotely." ${ }^{84}$

TEMA allows women to have abortions at home so they do not have to travel and be exposed to the infection, but it also protects health care providers from infection. ${ }^{85}$ There are big differences in the models in which TEMA appears today, for example it can be "a consultation by telephone or video call before abortifacients are posted to the patient". ${ }^{86}$ In its COVID-19 guidance on maintaining essential health services, the WHO emphasized the need to ensure safe abortion in accordance with the law and stressed the need to 'minimize facility visits' and to give priority to 'telemedicine and self-management approaches'. ${ }^{87}$ What must be satisfied is that pregnant women are informed "on effective protocols and access to follow up health care if needed." 88 The WHO recognized "the empowering role of self-managed abortion" and its crucial importance for the power and dignity of women. ${ }^{89}$ WHO's Model List of Essential Medicines that states are required to provide includes misoprostol and mifepristone. ${ }^{90}$

services for women in the EU, report made by Blagojević, A. and Tucak I., September 2020, [https:// www.europarl.europa.eu/RegData/etudes/IDAN/2020/659923/IPOL_IDA(2020)659923_EN.pdf], Accessed 20 April 2021.

80 Ibid.

81 Ibid., 1.

82 Romanis, E. C.; Parsons, J. A., op. cit., note 26, p. 2.

83 Ibid.

84 Ibid.

85 Ibid., 4.

86 Ibid., 2.

87 Ibid., 6. See WHO, Maintaining essential health services: operational guidance for the COVID-19 context, 1 June 2020, [https://apps.who.int/iris/handle/10665/332240], Accessed 1 June 2021.

88 Todd-Gher, J.; Shah, P. K., op. cit., note 25, p. 28. See WHO, WHO consolidated guidelines on selfcare interventions for health: sexual and reproductive health and rights, 2019, [https://www.who.int/ reproductivehealth/publications/self-care-interventions/en/], Accessed 1 June 2021.

89 Ibid., 29.

90 Ibid. WHO, WHO releases guidelines to help countries maintain essential health services during the COVID-19 pandemic, 2020. 
Some European countries, such as France, have allowed remote consultations with patients seeking abortion because of the risk of infection. Ireland and the United Kingdom also allowed home use of mifepristone and misoprostol. ${ }^{91}$ The UK has adopted guidelines that allow people who may become pregnant to manage the abortion process themselves. ${ }^{92}$ Under the new regulation, which is still temporary, a person seeking an abortion can have a telemedicine consultation with a medical practitioner, and use the mifepristone and misoprostol pills delivered to them by mail at home. ${ }^{93}$

Requirements in some states that those accessing EMI must be monitored in clinics when consuming active medical abortion drugs ${ }^{94}$ mifepristone and misoprostol, in situations where it is not medically necessary, portray women as "irresponsible, not trustworthy, and / or are incapable of making their own decisions about abortion". ${ }^{95}$ Removing medically unnecessary abortion restrictions is not just about reducing possible harm but is "a human rights imperative". ${ }^{96}$ States have a positive human rights obligation to ensure access to safe abortion. ${ }^{97}$ Thus, enabling self-managed abortion, i.e. access to medicines and telemedicine counselling, and not punishing such behavior is a step towards fulfilling these obligations. ${ }^{98}$

\subsection{Poland}

The spread of so-called "illiberal democracies," 99 or the development of illiberalism in Central and Eastern Europe, has been linked particularly with Poland and Hungary, and is characterized by the crisis of democracy and backsliding, meaning the creation of societies "that chose the path towards democratization, but returned to bad habits instead". ${ }^{100}$ The functioning of "sophisticated $21^{\text {st }}$-century

\footnotetext{
$91 \quad$ Ibid., 28.

92 Prandini Assis, M.; Larrea, S., op. cit., note 16, p. 1.

93 Ibid.

94 Todd-Gher, J.; Shah, P. K., op. cit., note 25, p. 29.

95 Romanis, E. C.; Parsons, J. A., op. cit., note 26, p.7.

96 Todd-Gher, J.; Shah, P. K., op. cit., note 25, p. 28.

$97 \quad$ Ibid.

98 Ibid., 29.

99 Smerdel, B., Kognitivna disonanca ili promjena paradigme? Kriza ili propast ustavne demokracije: što nakon populističke kontrarevolucije?, in: Ustavne promjene i političke nagodbe. Republika Hrvatska između demokracije i populizma, HAZU, Zagreb, 2021, p. 66.

100 Kostadinov, B., Vladavina prava - backsliding ili globalni kraj liberalne demokracije?, in: Ustavne promjene i političke nagodbe. Republika Hrvatska između demokracije i populizma, HAZU, Zagreb, 2021, p. 367.
} 
authoritarians" and the creation of a "Frankenstate" was explained by K.L. Scheppele using Hungary as a model applicable to Poland as well:

"A Frankenstate is an abusive form of rule, created by combining the bits and pieces of perfectly reasonable democratic institutions in monstrous ways, much as Frankenstein's monster was created from bits and pieces of other living things. No one part is objectionable; the horror emerges from the combinations. As a result, if one approaches the monster with a checklist, the monster will pass the test (elections, CHECK; parliamentary government, CHECK). But the combinations - free elections with a paucity of parties; a unicameral parliament without independent "transparency institutions" like ombudsmen and audit offices - are where the problems lie." 101

In the case of Poland, the practice consists of the opportunistic utilization of the constitutional provisions and the selective choice of "appropriate" constitutional provisions, dubbed "illiberal remodelling" by Drinóczi and Bień-Kacala. The term describes the practice of "governments routinely apply[ing] the illiberal version of the Rule of Law (illiberal legality)" 102 , which has been detected even before COVID-19. In the last few years, the European Parliament adopted several resolutions with which it addressed the situation concerning respect for the rule of law, human rights and democracy in Poland. Within this context, the European Parliament resolutions of 13 April $2016^{103}$ and 14 September $2016^{104}$ on the situation in Poland regarding the impact of recent developments on fundamental rights, and the European Parliament Resolution of 15 November $2017^{105}$ on the situation of the rule of law and democracy in Poland, and that of 17 September $2020^{106}$ on the proposal for a Council decision on the determination of a clear risk of a serious

101 Scheppele, K. L., Not Your Father's Authoritarianism: The Creation of the "Frankenstate", APSA, European Politics \& Society, 2013, p. 5, available on: [https://www.democratic-erosion.com/wp-content/ uploads/2018/03/Scheppele-2013.pdf], Accessed 10 April 2021.

102 Drinóczi, T., Bień-Kacala, A., COVID-19 in Hungary and Poland: extraordinary situation and illiberal constitutionalism, The Theory and Practise od Legislation, Vol. 8, 2020, p. 171, available on: [https:// www.tandfonline.com/doi/full/10.1080/20508840.2020.1782109], Accessed 10 April 2021.

103 European Parliament Resolution of 13 April 2016 on the situation in Poland (2015/3031(RSP)), available on: [https://www.europarl.europa.eu/doceo/document/TA-8-2016-0123_EN.html], Accessed 4 April 2021.

104 European Parliament Resolution of 14 September 2016 on the recent developments in Poland and their impact on fundamental rights as laid down in the Charter of Fundamental Rights of the European Union (2016/2774(RSP)), available on: [https://www.europarl.europa.eu/doceo/document/TA-82016-0344_EN.pdf?redirect], Accessed 5 April 2021.

105 European Parliament Resolution of 15 November 2017 on the situation of the rule of law and democracy in Poland (2017/2931(RSP)), available on: [https:/www.europarl.europa.eu/doceo/document/ TA-8-2017-0442_EN.pdf?redirect], Accessed 4 April 2021.

106 European Parliament Resolution of 17 September 2020 on the proposal for a Council decision on the determination of a clear risk of a serious breach by the Republic of Poland of the rule of law (COM(2017)0835), available on: [https://www.europarl.europa.eu/doceo/document/TA-9-20200225_EN.html], Accessed 4 April 2021. 
breach of the rule of law by Poland deserve special attention. The latter Resolution addresses three critical areas: the functioning of the legislative and electoral system, the independence of the judiciary and the protection of fundamental rights (para. 1). This is also a Resolution in which the parts on sexual and reproductive health and rights (paras. 56 and 57) call on the Polish authorities "to take measures to implement fully the judgments handed down by the European Court of Human Rights in cases against Poland, which has ruled on several occasions that restrictive abortion laws and lack of implementation violate the human rights of women." In the recent Interim Resolution the Committee of Ministers of the Council of Europe, which supervises the execution of the final judgements of the European Court of Human Rights, expressed concern over the lack of information on any measures putting in place with regard to the execution of the judgements Tysiac, $R$. R. and P. and S. against Poland, and called on Poland to adopt clear and effective procedures for women to access lawful abortion. ${ }^{107}$

Even before the COVID-19 pandemic, Poland was considered one of the EU countries with the most restrictive abortion law. However, it is interesting to note that the Polish legal system used to be significantly more liberal during the Communist regime, ${ }^{108}$ whereas the current abortion law from 1993 (with subsequent amendments) made abortion illegal with a few exceptions as follows:

" 1 . If the pregnancy constitutes a threat to the life or health of the mother; 2. If the pre-natal examination or other medical reasons point to a high probability of severe and irreversible damage to the foetus or on an incurable life-threatening disease of the child; 3. If there is a confirmed suspicion that the pregnancy is a result of a criminal act, the termination of the pregnancy in this case is allowed, if the woman is less than 12 weeks pregnant." ${ }^{\prime 109}$

Even before COVID-19, there has been significant variation in access to abortion within the EU, but the data on access to abortion in Poland show that Polish women were faced with an extremely difficult situation even before the pandemic. This claim is supported by the following data from the European Parliament

107 Interim Resolution CM/ResDH(2021)44, Execution of the judgements of the European Court of Human Rights Tysiąc, R. R. and P. and S. against Poland, adopted by the Committee of Ministers on 11 March 2021, available on: [https://search.coe.int/cm/Pages/result_details.aspx?ObjectID=0900001680a1bdc4], Accessed 4 April 2021.

108 Blagojević, A., Tucak, I., Rethinking the right to abortion, Balkan Social Science Review, Vol. 15, 2020, p. 136.

109 European Parliament, Directorate general for internal policies, Policy department C: Citizens' rights and constitutional affairs, The Policy of Gender Equality in Poland - Update, 2016, p. 30, available on: [https://www.europarl.europa.eu/RegData/etudes/STUD/2016/571372/IPOL_STU(2016)571372_ EN.pdf], Accessed 5 April 2021. 
Resolution of 26 November $2020:{ }^{110}$ before the pandemic, roughly only $10 \%$ of hospitals contracted by the Polish National Health Fund provided legal abortions; doctors preferred not to be associated with abortion and widely invoked the conscience clause; it is estimated that about 200,000 women illegally terminated their pregnancies each year in Poland, while about 30,000 were forced to travel abroad to seek abortion and thus incur additional expenses. This brings into question the equal accessibility to all women, especially the socio-economically disadvantaged women and ultimately leads to the conclusion that safe abortion is only accessible to a limited group of women in Poland (paras. K., L and O. of the Resolution).

It should also be noted that for many years in Poland there have been periodic petition initiatives linked to the Catholic Church and pro-life organizations with the goal of amending the existing legislation to introduce an abortion ban or at least a more restrictive abortion law. For this reason, for example, an initiative called the Committee for Legislation Action "Stop Abortion" was formed in March 2016. It collected 450,000 signatures (the Constitution requires 100,000 signatures) for the total ban on abortion. ${ }^{11}$ The initiative resulted in a string of protests and the mobilization of women's NGOs, but also in the creation of a counter-initiative named Committee for Legislation Action "Save the Women", which proposed the liberalization of abortion law and also successfully collected 250,000 signatures. ${ }^{112}$ Two years later, also owing to mass "Black Monday" protests, and international attention and support, attempts to introduce a more restrictive abortion law were thwarted. ${ }^{113}$

It appears that the COVID-19 pandemic represented the perfect moment for the fulfilment of years-long efforts to enact a near-total ban on abortion. Guasti states that the Covid-19 pandemic "represents a new and unparalleled stress-test for the already disrupted liberal-representative democracies", ${ }^{114}$ which has, in the case of the four Central European countries, or the so-called Visegrad Four, resulted in "fostering the rise of authoritarianism" and "illiberal swerving". ${ }^{115}$

110 European Parliament Resolution of 26 November 2020 on the de facto ban on the right to abortion in Poland (2020/2876(RSP)), available on: [https://www.europarl.europa.eu/doceo/document/TA-92020-0336_EN.html], Accessed 5 April 2021.

111 The Policy of Gender Equality in Poland, op. cit., note 109, pp. 30-31.

112 Ibid.

113 Euronews: Huge protests in Poland over near-total abortion ban, 23 March 2018, available on: [https://www.euronews.com/2018/03/23/huge-protests-in-poland-over-near-total-abortion-ban], Accessed 4 April 2021.

114 Guasti, P., The Impact pf the COVID-19 Pandemic in Central and Eastern Europe. The Rise of Autocracy and Democratic Resilience, Democratic Theory, Vol. 7. Issue 2, 2020, p. 47.

115 Ibid., p. 49. 
This "illiberal swerving" in the times of pandemic in Poland had begun as early as two days before the first case of COVID-19 was diagnosed in the country, on 2 March 2020, ${ }^{116}$ when the Polish Parliament (Sejm) adopted the Covid-19 Act and continued with the adoption of "massive and chaotic legislation", ${ }_{117}$ commonly called "anti-crisis shield". ${ }^{118}$ However, instead of declaring a "state of emergency" on the basis of the 1997 Constitution, the ruling majority introduced the "state of epidemic" under the ordinary law. ${ }^{19}$ The problem also lies in the fact that the introduced measures are "stricter than those that may be applied during the 'state of natural disaster', ${ }^{120}$ and in some cases, they could also seen as unconstitutional, ${ }^{121}$ particularly in relation to political rights, and especially in relation to the right to assembly. The additional constitutional issue is that in this state of affairs, the power of the executive branch is too dominant, concurrently weakening the 'checks and balances, parliamentary oversight, and the court"'. ${ }^{122}$

Applying the "state of epidemic" the Government banned any kind of assemblies ${ }^{123}$ and introduced serious restrictions on freedom of movement. So, people were able to leave their homes only due to particularly justified reasons, such as going to work or grocery shopping. ${ }^{124}$ However, it is important to note that the ban on gathering is constitutional only if the "the state of emergency" or "the state of war" is declared beforehand; it is unconstitutional in the "state of epidemic." Even though, during a pandemic, certain restrictions on the right to public assembly would meet the requirements of "necessity and proportionality", a total ban during the pandemic violates the essence of this right. ${ }^{125}$

In those circumstances, the Sejm started a debate on legislative proposals on further restrictions on access to abortion and the criminalization of sex education with a proposed prison sentence of up to three years for teachers. ${ }^{126}$ On 15 April 2020, the Polish Parliament enacted the "Stop Abortion" bill, and then, however, one day later sent it for further considerations in the parliamentary committees.

\footnotetext{
116 Ibid., p. 53.

117 Drinóczi, T.; Bień-Kacala, A., op. cit., note 102, p. 18.

118 Ibid.

119 Przemyslaw, O., Limitations to the Right to Freedom of Assembly in Poland during the COVID-19 Pandemic: The Case of Women's Strike, HAPSc Policy Brief Series, 1(2), 2020, p. 197.

120 Ibid., p. 18.

121 Ibid.

122 Guasti, P., op. cit., note 114, p. 53.

123 Drinóczi, T.; Bień-Kacala, A., op. cit., note 102, p. 20.

124 Przemyslaw, O., op. cit., note 119, p. 196.

125 Drinóczi, T.; Bień-Kacala, A., op. cit., note 102, p. 20.

126 Guasti, P., op. cit., note 114, p. 53.
} 
In the meantime, mass protests all over Poland erupted again, but this time under new circumstances. Epidemiological restrictions were construed as "an excuse to limit civil liberties and prevent protests against government policy". ${ }^{127}$ Still, this has not stopped civic initiatives and supporters of the Women's Strike to protest by employing innovative measures such as protesting online or hanging banners from the balconies, windows, rear windshields and other visible locations. ${ }^{128}$

Finally, on 22 October 2020, the Polish Constitutional Tribunal addressed the issue of eugenic abortion, i.e., abortion where prenatal examinations indicate a high probability of serious and irreversible disability of the foetus or an incurable life-threatening illness and held that it is contrary to the Polish Constitution.

Once again, the timing was everything: the second wave of the pandemic and health-based restrictions impeding any proper democratic discussions, and the sanitary restrictions impeding the protests. In addition, as it is stated in the aforementioned European Parliament Resolution of 26 November 2020, the authorities employed threats to prevent citizen's participation in protests, and the national public prosecutor and Minister of Justice have presented that criminal charges which could result with a prison sentence up to eight years will be filed against the organizers of the protests. ${ }^{129}$ In that same Resolution, the European Parliament denounced the Constitutional Tribunal ruling and addressed it as a new attack on the rule of law and fundamental rights, particularly emphasising the fact that the "ruling was pronounced by judges elected by and totally dependent on politicians from the PiS (Law and Justice)-led coalition". ${ }^{130}$ In other words, it reiterated the concern over the legitimacy and independence of the judges of the Constitutional Tribunal.

The aforementioned ruling could in practice truly result in a total abortion ban in Poland, as data for 2019 show that the legal basis for 1074 of 1100 pregnancy terminations ${ }^{131}$ is precisely the one that the Constitutional Tribunal declared as unconstitutional. On the other hand, an almost total ban on the right to abortion in Poland will result in unsafe abortion, and the expansion of abortion tourism.

With regard to the protection of the right to abortion, the Slovak Republic is also under scrutiny. Pro-life supporters in Slovakia tried again last year to restrict access to abortion. In her letter of 7 September 2020 to the National Council of

\footnotetext{
127 Przemyslaw, O., op. cit., note 119, p. 199.

128 Ibid., p. 198.

129 European Parliament Resolution, op. cit. note 104, para. V.

130 Ibid., point $\mathrm{Z}$.

131 Ibid., point $\mathrm{Q}$.
} 
the Slovak Republic, the Commissioner for Human Rights of the Council of Europe drew attention to a proposal submitted by several members "of the National Council, for a Draft Law which Amends and Supplements Act No . 576/2004 Coll. of Laws on Healthcare, Healthcare-related Services, and Amending and Supplementing Certain Acts as Amended, and which Amends and Supplements Certain Acts (Print No. 154, 19 June 2020)”. ${ }^{132}$

In that proposal, the Commissioner for Human Rights recognized several controversial elements, in particular the extension of the mandatory waiting period, the "introduction of a new authorization requirement for performing abortions on health grounds, which would require two medical certificates attesting to such grounds, rather than one. as currently, except in the case of urgent care provision", and she also warned that changes "in relation to the provision of information on abortion and the collection and sharing of personal information have the potential to form substantial barriers to accessing safe and legal abortion services, and to stigmatize women seeking an abortion. The same is true for the proposed ban on 'advertising' abortion services". ${ }^{133}$

\subsection{Malta}

In the smallest country of the European Union and the only one with the complete legal ban of abortion, "barriers have always existed; COVID-19 has laid them bare". ${ }^{134}$

In the country whose Constitution proclaims Catholicism as the state religion, and where $90 \%$ of the population identifies as Catholic, ${ }^{135}$ strict abortion laws "date back to the time of the Order of the Knights of St John in the 1700s, and in the 1850s they were written and enacted, as they remain today." 136 According to Maltese law, a person who is guilty of procuring an abortion has a risk of 18 months' to 3 years' imprisonment, while doctors risk up to four years' imprisonment. ${ }^{137}$

\footnotetext{
132 Commissioner for Human Rights of the Council of Europe, [https://rm.coe.int/commdh-2020-18letter-to-parliament-slovak-republic-en/16809f7d70], Accessed 1 April 2021.

133 Ibid.

134 Caruana- Finkel, L., Abortion in the time of COVID-19: perspectives from Malta, Sexual and Reproductice Health Matters, 28 (1), 2020, p. 1, available on: [https://www.researchgate.net/publication/342064817_Abortion_in_the_time_of_COVID-19_Perspectives_from_Malta], Accessed 6 April 2021.

135 Gravino, G.; Caruana-Finkel, L., Abortion and methods of reproductive planning: the views of Malta's medical doctor cohort, Sexual and Reproductive Health Matters, Vol. 27, Issue 1, 2019, p. 287.

136 Ibid., p. 288.

137 Ibid.
} 
Despite the certain progressive developments in the society within the last few years, (for example, emergency contraceptive pills were introduced in 2016, and same-sex marriage was allowed in $2017^{138}$ ), with regard to reproductive rights, Malta is still called "a conservative bastion in Europe". 139

Even though in 2019 Malta saw the founding of a pro-choice movement, abortion is still a rather stigmatized area. Caruana-Finkel states that misinformation is spread through media, education and religious institutions, and many healthcare professionals are unwilling to provide relevant information about abortion, even they are legally obliged to do so. ${ }^{140}$ The result is that most abortion is done in secrecy and silence. ${ }^{141}$

It is estimated that every year around 370 women travel abroad for an abortion, whilst around 200 women purchase medical abortion pills. ${ }^{142}$ Like Polish women, many travel to other countries with liberal access to abortion, and here they depend on their financial costs, health, mobility. The other (illegal) option is to purchase medical abortion pills online and many organizations (such as Women on Web) help women in this regard. ${ }^{143}$

It is important to stress that, over the last decade, several international organizations demanded that Malta decriminalize abortion and ensure safe access to abortion. Criticism of Malta's abortion legislation has been expressed, for example, by two United Nation's Committees (on the Elimination of Discrimination Against Women in $2010^{144}$ and the Rights of the Child in 2019 ${ }^{145}$ ), and by the Council of Europe's Commissioner for Human Rights, who has repeatedly stressed that

138 Caruana-Finkel, L., op. cit., note 134, p. 1.

139 Galea, R., Abortion Debate in Malta: Between Progress, Catholic Morality and Patriarchy”, Green European Journal, 2020, p. 1, available on: [https:/www.greeneuropeanjournal.eu/abortion-debate-in-malta-between-progress-catholic-morality-and-patriarchy/], Accessed 6 April 2021.

140 Caruana-Finkel, L., op. cit., note 134, p. 1.1.

141 Ibid.

142 Gravino, G., Caruana-Finkel, L., op. cit., note 135, p. 289.

143 Caruana-Finkel, L., op. cit., note 134, p. 1.

144 United Nation's Committee on the Elimination of Discrimination of Women, Consideration of reports submitted by States parties under article 18 of the Convention, Concluding observations - Malta, 4-22 October 2010, see: point 35, available on: [https://www2.ohchr.org/english/bodies/cedaw/ docs/co/CEDAW-C-MLT-CO-4.pdf], Accessed 5 April 2021.

145 United Nation's Committee on the Rights of the Child, Concluding observations on the combined third to sixth periodic reports of Malta, 26 June 2019, see: point 33, avaliable on: [http://docstore. ohchr.org/SelfServices/FilesHandler.ashx?enc=6QkG1d\%2FPPRiCAqhKb7yhsg7\%2B4\%2FqMVk67oq8W3WL3NgfTU\%2FnqqHmXO4VldQOdNY5c3Pzf\%2F2kL\%2For9buMreMtLkTY0jcdvxzAXai8qhoQwIJIGHA7s55TPcAcPp2m8Q0ML], Accessed 5 April 2021. 
Malta's total ban of abortion goes against the international human rights norms and standards. ${ }^{146}$

Undoubtedly, COVID-19 put further emphasis on the problem of abortion in Malta. The closing of borders heightened the existing barriers and made the situation even worse. Due to the pandemic, travel restrictions resulted in an increased number of pregnant women who turn to abortion support groups and buy medical abortion pills online. ${ }^{147}$ Due to the fact that at the beginning of the pandemic the government did not include birth control bills in the list of essential medicines, it is likely to expect the growth in use of unsafe methods to end unwanted pregnancies. ${ }^{148}$ In its statement about the impact of COVID-19 on women' s sexual and reproductive rights of 7 May 2020, the Council of Europe Commissioner for Human Rights paid special attention to the situation in Malta and reiterated the fact that states must consider access to abortion care as an essential health care service to be maintained during the pandemic and take all necessary accompanying measures. ${ }^{149}$

\section{CONCLUDING REMARKS}

The COVID-19 pandemic is the largest "public health emergency" facing health systems in the 21 st century. ${ }^{150}$ It also reflected on the right of access to abortion, which is the most common surgical procedure women undergo. ${ }^{151}$ Throughout history, law and medicine have tried to establish control over women's sexual and reproductive rights in a discriminatory manner. ${ }^{152}$ They were instruments for "perpetuating gendered harms". ${ }^{153}$ We are still witnessing the remnants of this approach today in the form of various restrictions on the right of access to abortion. Those barriers differ from state to state and encompass different legal, social and procedural aspects, such as the limited capacity of abortion services and practitio-

\footnotetext{
146 See: Muižnieks, Niels, Need to reform abortion law, Times of Malta, 26 February 2018, available on: [https://timesofmalta.com/articles/view/need-to-reform-abortion-law-nils-muiznieks.671761], Accessed 5 April 2021.

147 Caruana-Finkel, L., op. cit., note 134, p. 2.

148 Ibid.

149 Council of Europe Commissioner for Human Rights, Statement: COVID-19: Ensure women's access to sexual and reproductive health and rights, May 7, 2020, available on: [https://www.coe.int/ca/ web/commissioner/-/covid-19-ensure-women-s-access-to-sexual-and-reproductive-health-and-rights], Accessed 5 April 2021.

150 Thomson, S., C.; Ip, E., op. cit., note 9, p. 1.

151 McGuinness, S.; Montgomery, J., op. cit., note 3, p. 37.

152 Ibid., 36.

153 Ibid.
} 
ners, high abortion fees, or mandatory pre-abortion counselling. ${ }^{154}$ In this paper, we investigated the legal systems of states that tried to facilitate women's access to abortion in the midst of the pandemic, but we also analyzed the legal systems of states with completely opposite approaches to the right to abortion. The emphasis in this second group was on the two countries that have the strictest abortion legislation in the European Union - Poland and Malta. We focused on "self-managed medical abortion via telemedicine". The acceptance of this model excludes the need for one or more visits to the clinic, mandatory waiting periods, excludes the ban on "telemedicine abortion counselling" and criminal sanctions for purchasing abortion medications by mail. ${ }^{155}$

Legal and policy measures to facilitate access to abortion, adopted by states during the pandemic, are temporary, but their positive effects on the protection of women's dignity and autonomy suggest that they should be maintained permanently. ${ }^{156}$ Today, abortion health care is recognized as "a human rights imperative; to protect the lives, bodily autonomy, and reproductive autonomy". ${ }^{157}$ Abortion must therefore be considered an "essential medical service". ${ }^{158}$ In the context of abortion, the role of the law is crucial. Its 'inner morality' places limits on possible abuse as a mechanism of 'oppression, stigmatization and an adverse determinant of health'. ${ }^{159}$ The law should not cause harm, but have a significant impact on gender justice and the reduction of discrimination. ${ }^{160}$

\section{REFERENCES}

\section{BOOKS AND ARTICLES}

1. Bennoune, K., "Lest We Should Sleep": COVID-19 and Human Rights, American Journal of International Law, Volume 114, No. 4, 2020, pp. 666 - 676

2. Blagojević, A., Tucak, I., Rethinking the right to abortion, Balkan Social Science Review, Vol. 15, 2020, pp. 135-157

3. Drinóczi, T., Bień-Kacala, A., COVID-19 in Hungary and Poland: extraordinary situation and illiberal constitutionalism, The Theory and Practice of Legislation, Vol. 8, [https://www. tandfonline.com/doi/full/10.1080/20508840.2020.1782109], Accessed 10 April 2021

\footnotetext{
154 Pinter et al., op. cit., note 57, pp. 56-57.

155 Todd-Gher, J.; Shah, P. K., op. cit., note 25, p, 29.

156 Romanis, E. C.; Parsons, J. A., op. cit., note 26, p. 7.

157 Ibid., 1.

158 UN Human Rights Committee. General Comment No. 29, UN Doc. CCPR/C/21/Rev.1/Add.11, 2001. Available from: [http://ccprcentre.org/ccpr-general-comments], Accessed 20 April 2021.

159 McGuinness, S.; Montgomery, J., op. cit., note 3, pp. 37-38; Fuller, L., The Morality of Law, New Have: Yale University Press, 1969.

160 Ibid., 38.
} 
4. Galea, R., Abortion Debate in Malta: Between Progress, Catholic Morality and Patriarchy, Green European Journal, 2020, [https://www.greeneuropeanjournal.eu/abortion-debatein-malta-between-progress-catholic-morality-and-patriarchy/], Accessed 6 April 2021

5. Gostin, L.; Monahan, J.; Kaldor, J.; Debartolo, M.; Friedman, E.; Gottschalk, K.; Kim, S. C.; Alwan, A.; Binagwaho, A.; Burci, G. L.; Cabal, L.; DeLand, K.; Evans, T. G.; Goosby, E.; Hossain, S.; Koh, H.; Ooms, G.; Periago, M. R.; Uprimny, R.; and Yamin, A. E., The Legal Determinants of Health: Harnessing the Power of Law for Global Health and Sustainable Development, The Lancet, 393, 2019, pp. 1857-1910.

6. Gravino, G., Caruana-Finkel, L., Abortion and methods of reproductive planning: the views of Malta's medical doctor cohort, Sexual and Reproductive Health Matters, Vol. 27, No. 1, 2019.

7. Guasti, P., The Impact pf the COVID-19 Pandemic in Central and Eastern Europe. The Rise of Autocracy and Democratic Resilience, Democratic Theory, Vol. 7., No. 2, 2020

8. Kostadinov, B., Vladavina prava - backsliding ili globalni kraj liberalne demokracije?, in: Ustavne promjene i političke nagodbe. Republika Hrvatska između demokracije i populizma, HAZU, Zagreb, 2021

9. Lebret, A., COVID-19 pandemic and derogation to human rights, Journal of Law and the Biosciences, Vol. 7, No. 1, 2020, pp. 1-15

10. McGuinness, S.; Montgomery, J., Legal Determinants of Health: Regulating Abortion Care, Public Health Ethics, Vol. 13, No. 1, 2020, pp. 34-40.

11. Mishtal, J, Martino, A., Zanini, G., Capelli, I., Rahm, L., DeZordo S., Political (in)action in abortion governance during COVID-19 in Europe: a call for a harmonized EU response during public health crises, Medical Anthropology Quarterly, 2020, [https://medanthroquarterly.org/rapid-response/2020/06/political-inaction-in-abortion-governance-during-covid19-in-europe/], Accessed 3 April 2021

12. Moreau, C.; Shankar, M.; Glasier, A.; Cameron, S.; Gemzel-Danielsson, K.; Abortion regulation in Europe in the era of COVID-19: a spectrum of policy responses, BMJ Sex Reproductive Health, 2020, [https://srh.bmj.com/content/familyplanning/early/2021/02/22/ bmjsrh-2020-200724.full.pdf], Accessed 3 April 2021

13. Mulligan, A., The Right to Travel for Abortion Services: A Case Study in Irish Cross-Border Reproductive Care, European Journal of Health Law, Vol. 22, No. 3, 2015, pp. 239-266

14. Nandagiri, R.; Coast, E.; Strong, J., COVID-19 and Abortion: Making Structural Violence Visible, International Perspectives on Sexual and Reproductive Health, Vol. 46, No. Supplement 1, Focus on Abortion (2020), pp. 83-89

15. Pinter, B., Aubeny, E., Bartai, G., Loeber, O., Ozalp, S., Webb, A., Accessibility and availability of abortion in six European countries, The European Journal of Contraception and Reproductive Health Care, Vol. 10, No. 1, 2005

16. Prandini Assis, M.; Larrea, S., Why self-managed abortion is so much more than a provisional solution for times of pandemic, Sexual and Reproductive Health Matters, Vol. 28, No. 1, 2020, 1779633, DOI: 10.1080/26410397.2020.1779633

17. Przemyslaw, O., Limitations to the Right to Freedom of Assembly in Poland during the COVID-19 Pandemic: The Case of Women's Strike, HAPSc Policy Brief Series, Vol. 1, No. 2, 2020

18. Romanis, E. C.; Parsons, J. A., Legal and Policy Responses to the Delivery of Abortion Care During COVID-19, International Journal of Gynecology and Obstetrics 2020 (Dec): 151.3: 
479-486, which has been published in final form at https://doi.org/10.1002/ijgo.13377, [https://obgyn.onlinelibrary.wiley.com/doi/epdf/10.1002/ijgo.13377], Accessed 3 April 2021

19. Scheppele, K. L., Not Your Father's Authoritariansim: The Creation of the "Frankenstate", APSA, European Politics \& Society, 2013, [https://www.democratic-erosion.com/wpcontent/uploads/2018/03/Scheppele-2013.pdf], Accessed 3 April 2021

20. Smerdel, B., Kognitivna disonanca ili promjena paradigme? Kriza ili propast ustavne demokracije: što nakon populističke kontrarevolucije?, in: Ustavne promjene i političke nagodbe. Republika Hrvatska izmectu demokracije i populizma, HAZU, Zagreb, 2021

21. Thomson, S., C.; Ip, E., COVID-19 emergency measures and the impending authoritarian pandemic, Journal of Law and the Biosciences, Vol. 7. No. 1. 2020, https://doi.org/10.1093/ jlb/lsaa064

22. Todd-Gher, J.; Shah, P. K., Abortion in the context of COVID-19: a human rights imperative, Sexual and Reproductive Health Matters, Vol. 28, No. 1, 2020, 1758394, DOI: 10.1080/26410397.2020.1758394

23. Tucak, I.; Blagojević, A., Abortion in Europe, EU and comparative law issues and challenges series (ECLIC), Vol. 4 (2020): EU 2020 - lessons from the past and solutions for the future, [https://hrcak.srce.hr/ojs/index.php/eclic/article/view/11943], Accessed 12 April 2021

24. Yamin, A. E.; Boghosian, T., Democracy and Health: Situating Health Rights within a Republic of Reasons, Yale J. Health Pol'y L. \& Ethics, Vol. 19, 2020, pp. 96-145

\section{EU LAW}

25. European Parliament Resolution of 13 April 2016 on the situation in Poland(2015/3031(RSP)), [https://www.europarl.europa.eu/doceo/document/TA-8-2016-0123_EN.html], Accessed 3 April 2021

26. European Parliament Resolution of 14 September 2016 on the recent development sin Poland and their impact on fundamental rights as laid down in the Charter of Fundamental Rights of the European Union (2016/2774(RSP)), [https://www.europarl.europa.eu/doceo/document/ TA-8-2016-0344_EN.pdf?redirect] Accessed 3 April 2021

27. European Parliament Resolution of 15 November 2017 on the situation of the rule of law and democarcy in Poland (2017/2931(RSP)), [https://www.europarl.europa.eu/doceo/document/TA-8-2017-0442_EN.pdf?redirect], Accessed 3 April 2021

28. European Parliament Resolution of 17 September 2020 on the proposal for a Council decision on the determination of a clear risk of a serious breach by the Republic of Polando $f$ the rule of law (COM(2017)0835), [https://www.europarl.europa.eu/doceo/document/TA-9-20200225_EN.html], Accessed 3 April 2021

29. European Parliament Resolution of 26 November 2020 on the de facto ban on the right to abortion in Poland (2020/2876(RSP)), [https://www.europarl.europa.eu/doceo/document/TA9-2020-0336_EN.html], Accessed 3 April 2021

30. European Parliament, Directorate general for internal policies, Policy department C: Citizens' rights and constitutional affairs, The Policy of Gender Equality in Poland - Update, 2016, [https://www.europarl.europa.eu/RegData/etudes/STUD/2016/571372/IPOL_ STU(2016)571372_EN.pdf], Accessed 3 April 2021 


\section{COUNCIL OF EUROPE}

1. Interim Resolution CM/ResDH(2021)44, Execution of the judgements of the European Court of Human Rights Tysiac, R. R. and P. and S. against Poland, adopted by the Committee of Ministers on 11 March 2021, [https://search.coe.int/cm/Pages/result_details.aspx?O bjectID=0900001680a1bdc4], Accessed 3 April 2021

2. Council of Europe Commissioner for Human Rights, Statement: COVID-19: Ensure women's access to sexual and reproductive health and rights, May 7, 2020, [https://www.coe. $\mathrm{int} / \mathrm{ca} / \mathrm{web} /$ commissioner/-/covid-19-ensure-women-s-access-to-sexual-and-reproductivehealth-and-rights], Accessed 3 April 2021

\section{UNITED NATIONS}

1. United Nation's Committee on the Elimination of Discrimination of Women, Consideration of reports submitted by States parties under article 18 of the Convention, Concluding observations - Malta, 4-22 October 2010, [https:/www2.ohchr.org/english/bodies/cedaw/ docs/co/CEDAW-C-MLT-CO-4.pdf], Accessed 3 April 2021

2. United Nation's Committee on the Rights of the Child, Concluding observations on the combined third to sixth periodic reports of Malta, 26 June 2019, [http://docstore.ohchr. org/SelfServices/FilesHandler.ashx?enc=6QkG1d\%2FPPRiCAqhKb7yhsg7\%2B4\%2FqM Vk67oq8W3WL3NgfTU\%2FnqqHmXO4VldQOdNY5c3Pzf\%2F2kL\%2For9buMreMt LkTY0jcdvxzAXai8qhoQwIJIGHA7s55TPcAcPp2m8Q0ML], Accessed 3 April 2021

\section{WEBSITE REFERENCES}

1. Blagojević, A., Tucak, I., Access to Abortion Services for Women in the EU, European Parliament's Committee on Women's Right and Gender Equality, 2020, [https:/www.europarl. europa.eu/thinktank/hr/document.html?reference=IPOL_IDA\%282020\%29659923], Accessed 12 April 2021

2. Caruana- Finkel, L., Abortion in the time of COVID-19: perspectives from Malta, Sexual and Reproductice Health Matters, Vol. 28, No. 1, 2020, [https://www.researchgate.net/publication/342064817_Abortion_in_the_time_of_COVID-19_Perspectives_from_Malta], Accessed 6 April 2021

3. IPPF European Network \& Euroepan Parliamentary Forum for Sexual and Reproductive Health and Rights, Sexual anad Reproductive Haelth and Rights during the COVID-19 pandemic, A joint report, 22 April 2020, [https://www.ippfen.org/sites/ippfen/files/2020-04/ Sexual\%20and\%20Reproductive\%20Health\%20during\%20the\%20COVID-19\%20pandemic.pdf], Accessed 6 April 2021

4. McBride, J., An Analysis of Covid-19 Responses and ECHR, 2020, [https://www.echrblog. com/2020/03/an-analysis-of-covid-19-responses-and.html], Accessed 3 April 2021 